\title{
関東ローム地盤における自立山留めの側圧と水平抵抗の評価 LATERAL EARTH PRESSURE AND LATERAL SUBGRADE REACTION OF BRACELESS EARTH RETAINING WALLS IN KANTO LOAM GROUND
}

\author{
元 井康 雄*
}

Yasuo MOTOI

\begin{abstract}
Lateral pressure and lateral subgrade reaction for designing earth retaining in Kanto loam ground were examined using field measurement, full scale horizontal load test, and analysis.

1. At earth retaining using soldier piles and lagging method, by enlarging intensity of cement bentonite enough to ground, cement bentonite carries out an action united with a soldier pile, and contributes to the increase in horizontal resistance.

2. Coefficient of lateral earth pressure counted backward from the actual measurement of displacement of earth retaining walls of 8 sites (16 points) in Kanto loam ground was distributed from 0.011 to 0.129.
\end{abstract}

Keywords : Earth retaining walls, Winklerian model, Subgrade reaction, Lateral earth pressure, Safety margin 山留め壁，梁ばねモデル，地盤反力，側圧，余裕度

1. 序

近年, 根切り山留めの計画において, 山留め架構の安全性の確保 に加え，周辺への影響を考慮した山留め変位量の抑制が必要となる ことが増加している。山留め壁の変位量を精度良く予測するために は, 荷重となる側圧と, 根入れ部の水平抵抗の評価が重要となるが, これらは一義的に設定されるものではなく，地盤のばらつきなどを 考慮した設計者の判断が要求される事項である。

側圧の評価法としては，軟弱地盤における山留めの外力分布を， 多数の実測変形から逆算的に検討した風間 ${ }^{11}$ ，2) の研究や， RC 連 続地中壁の壁面土圧実測值を基に宮崎らが提案した側圧係数の表 (以降，側圧係数表） 3)，4）が代表的である。側圧係数表は，側圧 係数を $0.2 \sim 0.8$ の範囲で地盤条件に応じて提案しており, 簡便かつ 設計者の経験や判断を活かせる利点から, 多数の適用実績がある。 ただし自立性の高い粘性土地盤や関東ロームなどでの比較的浅い根 切り山留め工事においては，通常，壁面土圧を実測しないため，側 圧係数表の推奨範囲に必ずしも包含されていない。また, 近年の研 究例えば5)，6）では, 関東ローム地盤における親杭横矢板壁の実測結 果から, 側圧係数が表の下限值 0.2 を下回ることが示唆されている。

一方, 浅い根切り山留め工事に多く適用される親杭横矢板壁の根 入れ部の水平抵抗の評価法としては，連続地中壁と同様に評価する 方法と，本設杭の水平抵抗の評価法を準用する方法とが示されてい る ${ }^{7)}$ 。前者は簡便で実用的であるが，親杭の寸法や設置間隔および 根固めの影響は山留め計算に反映されない。後者は, これらの影響
を考慮できる利点があるものの, 根入れ部分は $\mathrm{H}$ 形鋼と比較的剛性 の小さな地盤改良体との複合体であるため, 本設杭とは厳密には挙 動が異なると考えられる。しかしながら, 親杭の根固め部分の挙動 に着目した実験や研究は見当たらず, 実挙動が不明瞭なまま山留め 設計に適用されているのが実情である。上記の背景から, 本研究で は，関東ローム地盤のような自立性の高い地盤における山留め壁の 水平変位量予測に重要となる, 側圧および水平抵抗の評価法につい て，以下に着目して検討を行った(図 1)。

（1）根固め部の有無や強度・寸法が水平抵抗に与える影響を把握 するため, 関東ローム地盤における親杭の根入れ部を模擬した水平 載荷実験およびシミュレーション解析を行う。

（2）（1）で検討した水平抵抗の評価法を適用し，関東ローム地盤を 主とした複数の浅い根切り山留め工事の变位実測結果を逆解析して 側圧係数を推定し, 側圧係数と種々の地盤定数との関係を整理する。 （3）（1)，(2)の結果から，関東ローム地盤での山留め設計時におけ る側圧と水平抵抗を簡便に評価する方法を検討して (2)で用いた事 例に適用し, 山留め壁変位量の余裕度を示す。

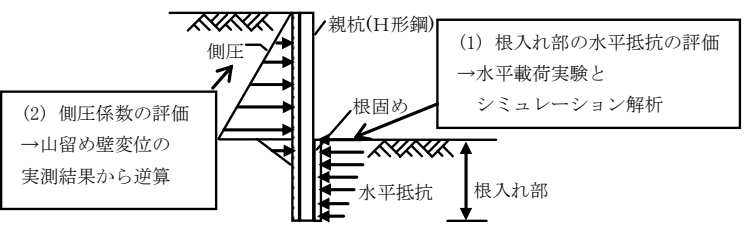

図 1 山留めの側圧と根入れ部の水平抵抗

\footnotetext{
* (侏)大林組技術研究所地盤技術研究部 主任研究員 $\cdot$ 工修

Chief Research Engineer, Geotechnical Engineering Department, Technical Research Institute, Obayashi Corp., M. Eng.
} 


\section{2. 関東ローム地盤における親杭の水平載荷実験}

親杭横矢板山留めにおける根固めの有無や強度・寸法が，親杭の 水平抵抗に与える影響を確認することを目的とし, 関東ローム地盤 において実大水平載荷実験を行った ${ }^{8)}$ 。

\section{2-1 実験地盤の概要}

図 2 に実験を実施した地盤の概要を示す。表層から GL-5.5m 付 近までは $\mathrm{N}$ 值 2 3 の関東ローム, その下に $\mathrm{N}$ 值 4 の砂質粘土, GL-6.8m 以深は $\mathrm{N}$ 值 50 以上の砂碟層がほぼ水平に堆積している。 GL-1.0，-3.0，-5.0m の一軸圧縮強さ $\mathrm{q}_{\mathrm{u}}$ と変形係数 $\mathrm{E}_{50}$ および孔内 水平載荷試験による変形係数 $\mathrm{E}_{\mathrm{b}}$ は，図中に示寸通りである。

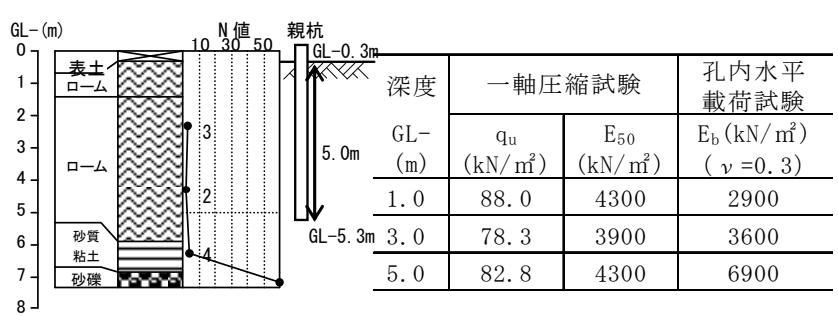

\section{図 2 地盤概要}

\section{2-2 実験装置および計測項目}

図 3 に実験装置の概要および計測項目を示す。全長 $5.5 \mathrm{~m}$ の $\mathrm{H}$ 形 鋼 $(\mathrm{H}-250 \times 250 \times 9 \times 14)$ を，表土部をすき取った地盤に $5.0 \mathrm{~m}$ 根入 れさせ，地表に突出させた部分に水平荷重を作用させた。地表面か らの載荷点高さ $\mathrm{h}$ は，計画值 $\mathrm{h}=0.15 \mathrm{~m} ，$ 実際は施工のばらつきに より図中に示す通りである。

荷重は 1 段階 $20 \mathrm{kN}$ として地盤が破壊するまで載荷し, 荷重速度, 荷重保持時間は,「杭の水平載荷試験方法・同解説」9)に示される一 方向多サイクルの試験方法に準拠した。杭体の計測項目は，杭頭(載 荷点)の変位と傾斜角, ひずみの深度分布である。また, トータルス テーションを用いて地表面の 3 次元変位を計測した(図 4)。

\section{$2-3$ 実験杭の仕様}

表 1 に，実験杭の仕様を示す。杭 No.1 は，根固めを用いない場 合を想定し，先行削孔せず $\mathrm{H}$ 形鋼を圧入で設置している。その他の 杭は根固めを施工し, 杭 No.2，3，4 は実験実施日における根固め の一軸圧縮強さがそれぞれ原地盤の 0.5 倍未満, 1.5 倍程度, 2 倍以 上となるような配合とし，根固め径は $0.45 \mathrm{~m}$ とした。杭 No.5，6 は，根固めの配合は杭 No.3 と同一とし，直径を $0.55 \mathrm{~m} ， 0.60 \mathrm{~m}$ と した。表 2 に根固めの配合を，表 3 に根固めの一軸圧縮試験結果を 示す。一軸圧縮強さは, プラントから直接採取した供試体の方が, 根固め施工中に孔内から採取した供試体に比べやや大きめの傾向を 示した。なお，実験は杭および根固め施工終了から，10１3 日経過 後の期間に実施している。

\section{2-4 杭の荷重一変位関係}

図 5 に杭 No.1 6 の水平荷重 $\mathrm{P}$ 一載荷点変位 $\mathrm{y}$ 関係の実測結果を 示す。図 6 は, 図 5 のうち, 載荷点変位 $20 \mathrm{~mm}$ 以下の部分を拡大し て示したものである。根固め配合 Type1 の杭 No.3，5，6 は， y= $10 \mathrm{~mm}$ 付近までは, 根固めなしの杭 No.1 と比較して水平抵抗がや
や大きく根固めの効果が認められるものの, 変位の増大に伴い, 杭 No.1 とほぼ同様の挙動を示すようになり, 大変形時においては根固 め径の相違による水平抵抗一の顕著な効果が認められなかった。

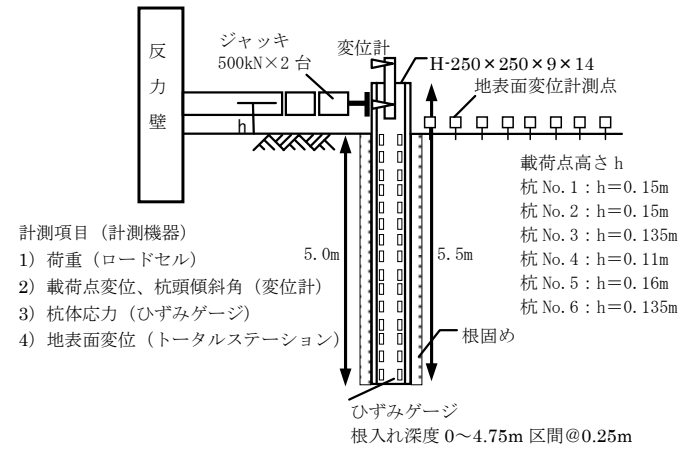

図 3 実験装置の概要および計測項目

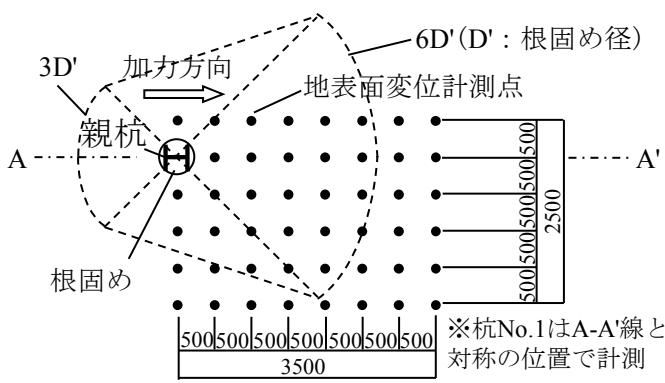

図 4 地表面変位の計測位置

\section{表 1 実験杭の仕様}

\begin{tabular}{|c|c|c|c|c|}
\hline 杭No. & 根固め直径 $(\mathrm{m})$ & 配合Type* & $\mathrm{H}$ 形鋼 & \begin{tabular}{|c|} 
根入れ \\
深さ $(\mathrm{m})$ \\
\end{tabular} \\
\hline 1 & なし (圧入) & なし & \multirow{6}{*}{$\begin{array}{l}\mathrm{H}-250 \times 250 \times 9 \times 14 \\
\text { ヤング係数 } \\
\mathrm{E}=2.05 \times 10^{5} \mathrm{~N} / \mathrm{mm}^{2} \\
\text { 断面 } 2 \text { 次モーメント } \\
\mathrm{I}=10700 \mathrm{~cm}^{4}\end{array}$} & \multirow{6}{*}{5.0} \\
\hline 2 & 0.45 & Type0 & & \\
\hline 3 & 0.45 & Type 1 & & \\
\hline 4 & 0.45 & Type2 & & \\
\hline 5 & 0.55 & Type1 & & \\
\hline 6 & 0.60 & Type1 & & \\
\hline
\end{tabular}

表 2 根固めの配合

\begin{tabular}{|c|c|c|c|c|}
\hline \multirow[b]{2}{*}{ 配合Type } & \multicolumn{3}{|c|}{ 1バッチ $\left(0.3 \mathrm{~m}^{3}=300 \mathrm{~L}\right)$ あたり } & \multirow[b]{2}{*}{$\begin{array}{c}\text { 水セメント } \\
\text { 比 } W / C\end{array}$} \\
\hline & \begin{tabular}{|c}
$\begin{array}{c}\text { セメント } \\
(\mathrm{kg})\end{array}$ \\
\end{tabular} & $\begin{array}{c}\text { ベントナイト } \\
(\mathrm{kg}) \\
\end{array}$ & $\begin{array}{l}\text { 水 } \\
\text { (L) }\end{array}$ & \\
\hline Type0 & 25 & 25 & 282 & $1128 \%$ \\
\hline Type1 & 50 & 25 & 274 & $548 \%$ \\
\hline Type2 & 62.5 & 25 & 270 & $432 \%$ \\
\hline
\end{tabular}

表 3 根固めの一軸圧縮試験結果

\begin{tabular}{c|c|c|c|c|c|c}
\hline 杭 & 配合 & 材令 & \multicolumn{2}{|c|}{ 一軸圧縮強さ $\mathrm{q}_{\mathrm{u}}\left(\mathrm{kN} / \mathrm{m}^{2}\right)$} & \multicolumn{2}{|c}{ 変形係数 $\mathrm{E}_{50}\left(\mathrm{kN} / \mathrm{m}^{2}\right)$} \\
\cline { 4 - 7 } No. & Type & $($ 日 $)$ & プラント採取 & 杭孔採取 & プラント採取 & 杭孔採取 \\
\hline \multirow{2}{*}{2} & Type0 & \multirow{2}{*}{10} & $\begin{array}{c}30.6 \\
(80.2)\end{array}$ & $\begin{array}{c}36.4 \\
(73.4)\end{array}$ & $\begin{array}{c}5000 \\
(16900)\end{array}$ & $\begin{array}{c}7100 \\
(15300)\end{array}$ \\
\hline \multirow{2}{*}{3} & \multirow{2}{*}{ Type1 } & \multirow{2}{*}{11} & $\begin{array}{c}136.6 \\
(351.2)\end{array}$ & $\begin{array}{c}120.6 \\
(244.1)\end{array}$ & $\begin{array}{c}23300 \\
(77000)\end{array}$ & $\begin{array}{c}22500 \\
(58200)\end{array}$ \\
\hline \multirow{2}{*}{4} & \multirow{2}{*}{ Type2 } & \multirow{2}{*}{12} & $\begin{array}{c}256.6 \\
(502.0)\end{array}$ & $\begin{array}{c}219.8 \\
(381.5)\end{array}$ & $\begin{array}{c}32300 \\
(87800)\end{array}$ & $\begin{array}{c}35300 \\
(83700)\end{array}$ \\
\hline \multirow{2}{*}{5} & \multirow{2}{*}{ Type1 } & \multirow{2}{*}{13} & $\begin{array}{c}161.1 \\
(351.2)\end{array}$ & $\begin{array}{c}154.5 \\
(244.1)\end{array}$ & $\begin{array}{c}25300 \\
(77000)\end{array}$ & $\begin{array}{c}28200 \\
(58200)\end{array}$ \\
\hline \multirow{2}{*}{6} & \multirow{2}{*}{ Type1 } & \multirow{2}{*}{12} & $\begin{array}{c}134.1 \\
(351.2)\end{array}$ & $\begin{array}{c}124.6 \\
(244.1)\end{array}$ & $\begin{array}{c}25300 \\
(77000)\end{array}$ & $\begin{array}{c}22600 \\
(58200)\end{array}$ \\
\hline
\end{tabular}

( )内数值は材令 28 日供試体の試験結果 (参考值) 
一方, 根固めの一軸圧縮強さが $200 \mathrm{kN} / \mathrm{m}^{2}$ 以上と大きな杭 No.4(配 合 Type2)の水平抵抗は, 水平地盤反力係数, 最大地盤反力ともに杭 No.1，3，5，6 と比較して明確に大きく, 反対に一軸圧縮強さが 40 $\mathrm{kN} / \mathrm{m}^{2}$ 未満と小さな杭 No.2(配合 Type0)ではその逆の性状を示し, 根固めの強度による差異が明瞭に現れた。

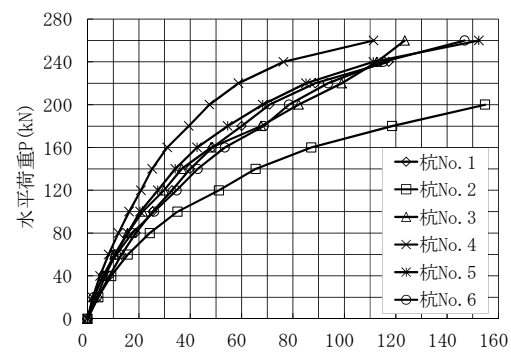

図 5 水平荷重 $\mathrm{P}$ 一載荷点変位 $\mathrm{y}$ 関係

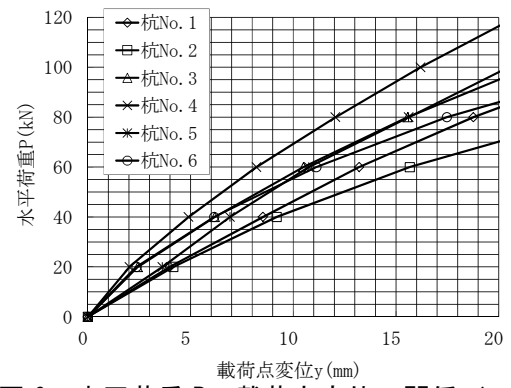

図 6 水平荷重 $\mathrm{P}$ 一載荷点変位 $\mathrm{y}$ 関係 $(\mathrm{y} \leqq 20 \mathrm{~mm})$

\section{2-5 根固めおよび地盤の挙動観察結果}

前節で示した性状の要因を考察するため, 図 7 に根固め上面の目 視観察結果を模式的に示した。杭 No.3〜 6いずれの根固めも, 載荷 の初期段階から図 7(a)の a-a', b-b'のような亀裂が生じた。初期段 階では b-b'の延長上の土塊が一体に挙動するが, 荷重増加に伴い, 図 7(b)の c-c'面で押抜きせん断破壞が発生し, 以降は $\mathrm{a}-\mathrm{a}^{\prime}$ の延長上 の土塊のみが一体に挙動した。即ち, 水平抵抗の見付け幅として考 慮できる幅は, 図 7(a)の状態ではほぼ根固め径, 図 7(b)の状態に移 行後は H 形鋼のフランジ幅のみになると言える。配合 Type1 の杭 No.3，5，6 では根固めと原地盤との強度の差がわずかであったた め, 上記の移行が早期の荷重段階である $40 \mathrm{kN}$ から $60 \mathrm{kN}$ に増加中 （載荷点変位 $\mathrm{y}=6 \sim 10 \mathrm{~mm}$ 程度）に生じ, 根固め径による差異が水 平抵抗にほとんど現れなかったものと考えられる。一方, 根固めの 効果が明瞭であった配合 Type2 の杭 No.4 では上記の移行が $180 \mathrm{kN}$ から $200 \mathrm{kN}$ への荷重段階（載荷点変位 $\mathrm{y}=40 \sim 50 \mathrm{~mm}$ 程度）で生じ た。なお, 根固めを用いない杭 No.1 では, 初期荷重の段階から図 7(b)のような原地盤の押抜きせん断破壊が認められた。また, 根固 め強度の低い杭 No.2(配合 Type0)では，根固めを用いない杭 No.1 よりも水平抵抗が小さいが，これは根固め内部において押抜きせん 断破壊が先行し, 原地盤の水平抵抗が十分に発揮されていないため である。

図 8 に, 杭 No.1 および杭 No.4 の最終載荷段階における地表面の 実測水平変位量の分布を対比して示す。杭 No.4 は, 根固めと杭が 一体となって挙動するため, 周辺地盤への影響範囲も広く, この地 盤反力が水平抵抗の増大に寄与している。したがって, 原地盤と比 較して十分に大きな強度の根固めとした場合は, 根固め径を考慮し
た水平抵抗を評価することが可能であると言える。

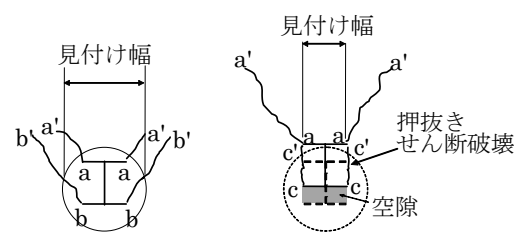
(a) 初期段階
(b) 押抜きせん断破壊後

図 7 根固め上面の亀裂発生状況 (模式図)

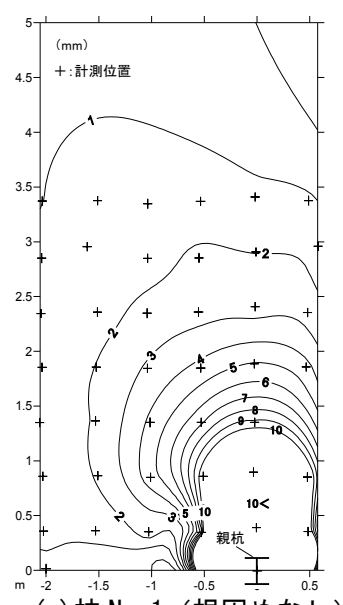

(a) 杭 No. 1 (根固めなし)

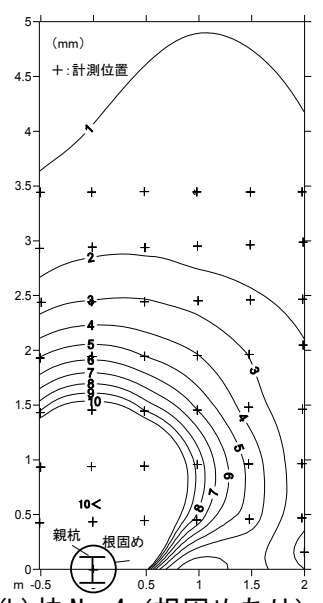

(b) 杭 No. 4 (根固めあり)
図 8 地表面の実測水平変位量

\section{3. シミュレーション解析に基づく関東ローム地盤の水平抵抗}

2 章の実験結果を弾性支承ばりモデルによりシミュレーション解 析し, 親杭の水平地盤反力係数を検討した。解析方法として, 杭体 と地盤の非線形性状および杭の見付け幅を考慮することが可能な直 接反復法 ${ }^{10)}$ を用いた。

\section{3-1 弾性支承ばりモデルによる解析方法の概要}

直接反復法は, 多層地盤中の杭を対象とし, 杭体を梁, 地盤の水 平抵抗をばねに置換し，(1)式を基本方程式として水平載荷時の杭の 応答を求める解析法である。杭及び地盤の非線形性状は, 杭体の曲 げ剛性 $\mathrm{EI}$ および水平地盤反力係数 $\mathrm{k}_{\mathrm{h}}$ を図 9 に示すように $\mathrm{M}($ モー

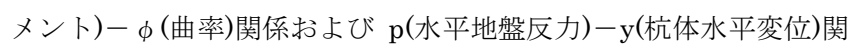
係曲線の割線係数として与えて収斂計算させて評価している。解析 上の深度方向の分割長は $0.25 \mathrm{~m}$, 収斂誤差は $0.1 \mathrm{~mm}$ 未満とした。

$$
\text { EI } \frac{d^{4} y}{d x^{4}}+k_{h} B y=0
$$

ここに, $\mathrm{E}:$ 杭のヤング係数 $\left(\mathrm{kN} / \mathrm{m}^{2}\right), \mathrm{I}$ : 杭の断面 2 次モーメン $卜\left(\mathrm{~m}^{4}\right), \mathrm{y}:$ 杭の水平変位 $(\mathrm{m}), \mathrm{x}$ : 深度 $(\mathrm{m}), \mathrm{k}_{\mathrm{h}}$ : (2)式で定義する 水平地盤反力係数 $\left(\mathrm{kN} / \mathrm{m}^{3}\right), \mathrm{B}$ : 杭径 $(\mathrm{m})$ を表す。

$$
\mathrm{k}_{\mathrm{h}}=\mathrm{k}_{\mathrm{h} 0} \cdot \bar{y}^{-1 / 2}
$$

ここに, $\mathrm{k}_{\mathrm{h} 0}$ : 基準水平地盤反力係数 $\left(\mathrm{kN} / \mathrm{m}^{3}\right)$ で, 杭の水平変位量 が $1 \mathrm{~cm}$ のときの $\mathrm{kh}, \overline{\mathrm{y}}$ : 杭の水平変位を $\mathrm{cm}$ で表した時の無次元化 量を表す。

なお，根固めの曲げ剛性は，表 3 に示寸杭孔採取供試体の試験当 日の変形係数 $\mathrm{E}_{50}$ の 5 倍を初期の変形係数 $\mathrm{E}_{0}$ と仮定 ${ }^{11)} し て \mathrm{E}_{0} \times \mathrm{I}$ を算出寸ると，親杭の EI に対し $0.3 \sim 3.3 \%$ 程度であり,ここでは 水平挙動への影響は小さいと考え解析上は無視した。 


\section{3-2 基準水平地盤反力係数 $\mathrm{k}_{\mathrm{h} 0}$ の評価}

表 4 に各地盤調查結果から推定した変形係数 $\mathrm{E}_{0}$ および(3)式 ${ }^{10}$ ) により求めた基準水平地盤反力係数 $\mathrm{k}_{\mathrm{h} 0}$ を示す。以降の検討では GL-2.75m および GL-4.75m を境界として地層を 3 分割し, 各深度 の一軸圧縮試験の $\mathrm{E}_{50}$ から $\mathrm{k}_{\mathrm{h} 0}$ を評価している。

$$
\mathrm{k}_{\mathrm{h} 0}=\alpha \cdot \mathrm{E}_{0} \cdot \mathrm{D}^{-3 / 4}
$$

ここに, $\alpha$ : 評価法によって決まる定数 $\left(\mathrm{m}^{-1}\right)$ で粘性土として評価 (表 4 の欄外参照), $\mathrm{E}_{0}$ : 変形係数 $\left(\mathrm{kN} / \mathrm{m}^{2}\right)$ (表 4 の欄外参照), $\mathrm{D}$ : 杭 径を $\mathrm{cm}$ で表した無次元数值, 表 4 の $\mathrm{k}_{\mathrm{h} 0}$ は $\mathrm{D}=25$ とした值である。

\section{3-3 水平抵抗の解析結果およびその考察}

図 10(a) ( c) に直接反復法による水平荷重 $\mathrm{P}$ 一載荷点変位 $\mathrm{y}$ 関係 の解析結果を実測值と併せて示す。解析における D は, 杭 No.1 6 の全てについて $\mathrm{H}$ 形鋼のフランジ幅に相当する $\mathrm{D}=25$ とし, 杭 No.4 については根固め径に相当する $\mathrm{D}=45$ とした解析結果も示した。ま た比較のため, 一様地盤中の弾性支承梁の解(以下, Chang の方法) による計算結果も併記した。Chang の方法においては，杭体は線形 弾性体とし, $\mathrm{k}_{\mathrm{h} 0}$ は 3 深度の平均值とする一様地盤とした。ただし, 地盤の非線形性状を考慮するため, 計算で得た地表面変位量 $\mathrm{yg}_{\mathrm{g}}$ (2) 式に適用して水平地盤反力係数 $\mathrm{kh}_{\mathrm{h}}$ を再評価し, $\mathrm{yg}_{\mathrm{g}}$ の誤差が $0.1 \mathrm{~mm}$ 未満となるように収斂計算している。図 10(a)には(3)式において $\mathrm{D}=25$ (H 形鋼フランジ幅) とした解析結果を, 根固めなしの杭 No.1 および根固め配合 Type0 の杭 No.2 の実測值と併せて示したが，杭 No.1 では，直接反復法および Chang の方法の結果ともに，実測值 と良く対応していることが分かる。一方，根固めの強度の低い杭 No.2では, $2-5$ 節で示したように根固め内部で先行する押抜きせ 儿断破壊による挙動が支配的であるため, 表 4 の地盤定数による解 析結果は実測值と対応しない結果となった。図 10 (b)には，(3)式に おいて $\mathrm{D}=25$ とした解析結果を, 根固め配合 Type1 の杭 No.3，5, 6 の実測值と併せて示した。2-5 節の根固め上面の挙動観察結果 より, 載荷点変位が $10 \mathrm{~mm}$ 未満である早期の段階で根固めの効果が 小さくなると考え，(3)式における D として，ここでは根固め径を考 慮せず， $\mathrm{H}$ 形鋼のフランジ幅に相当する $\mathrm{D}=25$ としたが，解析值は 実測值と概ね対応した。また, 直接反復法では杭体の非線形性を評 価しているため, Chang の方法と比較して大変形時まで実測挙動と の対応が良い。図 10 (c)には, 根固め強度の大きい杭 No.4の実測值 および(3)式で $\mathrm{D}=25, \mathrm{D}=45$ (根固め径) とした解析值を示した。載 荷点変位が $30 \mathrm{~mm}$ 付近までは直接反復法において $\mathrm{D}=45$ とした解析 值が実測值とほぼ一致し，根固め径の効果が水平抵抗に明確に現れ ている。ただし, 以降の変位の増大に伴い $\mathrm{D}=25$ とした解析值が実 測值と対応寸るように移行し, 根固めの効果が低減していく。これ は，2-5 節で示した根固め部分の破壊挙動と良く対応している。

図 11 に杭体応力の深度分布の例（杭 No.4, D=45）を示す。直接 反復法による結果は, 大変形時において杭体が塑性化した範囲で実 測值との差異が認められるものの，全深度にわたり実測值と概㸚対 応している。Chang の方法によると, 荷重の増大に伴い深度 $2.0 \mathrm{~m}$ 以深での実測值との差異が顕著となる。

上記から考察した, 親杭根入れ部の水平抵抗の評価をまとめる。 （1）弾性支承ばりモデルに杭体および地盤の非線形性状を考慮し た直接反復法により, 親杭根入れ部の水平挙動を精度良く解析でき
ることを確認した。地盤反力の評価方法としては，一軸圧縮試験の 変形係数 $\mathrm{E}_{50}$ から基準水平地盤反力係数 $\mathrm{k}_{\mathrm{h} 0}$ を評価し, これを杭体 水平変位量の平方根に反比例させる方法を導入した。実験のシミュ レーションを目的として杭体は弾塑性体として評価したが，通常の 山留めでは，杭体は弾性領域内で設計するため，変位予測において は, 杭体の非線形性状は解析上考慮せず線形弾性体として評価し, 杭体応力が弾性領域以内であることを確認しても良い。
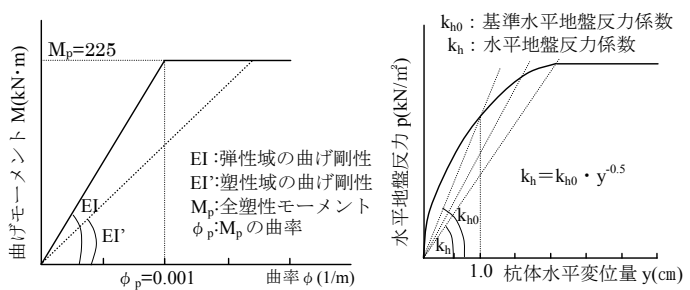

図 9 杭体の $M-\phi$ 関係および地盤の $\mathrm{P}-\mathrm{y}$ 関係

表 4 変形係数 $\mathrm{E}_{0}$ および基準水平地盤反力係数 $k_{h 0}$

\begin{tabular}{|c|c|c|c|c|c|c|}
\hline \multirow{3}{*}{ 試験深度 } & \multicolumn{2}{|c|}{ 一軸圧縮試験 } & \multicolumn{2}{|c|}{ N值 } & \multicolumn{2}{|c|}{ 孔内水平載荷試験 } \\
\hline & $E_{0}$ & $\mathrm{kh}_{\mathrm{o}}$ & $\mathrm{E}_{0}$ & $\mathrm{kh}_{0}$ & $E_{0}$ & $\mathrm{kh}_{\mathrm{o}}$ \\
\hline & $\left(\mathrm{kN} / \mathrm{m}^{2}\right)$ & $\left(\mathrm{kN} / \mathrm{m}^{3}\right)$ & $\left(\mathrm{kN} / \mathrm{m}^{2}\right)$ & $\left(\mathrm{kN} / \mathrm{m}^{3}\right)$ & $\left(\mathrm{kN} / \mathrm{m}^{2}\right)$ & $\left(\mathrm{kN} / \mathrm{m}^{3}\right)$ \\
\hline GL-1.0m & 4,300 & 30,600 & 2,100 & 11,300 & 2,900 & 20,600 \\
\hline $\mathrm{GL}-3.0 \mathrm{~m}$ & 3,900 & 28,200 & 1,400 & 7,500 & 3,600 & 25,500 \\
\hline GL-5.0m & 4,300 & 30,500 & 2,800 & 15,000 & 6,900 & 49,100 \\
\hline 平均 & 4,200 & 29,800 & 2,100 & 11,300 & 4,400 & 31,700 \\
\hline & $\begin{array}{l}\mathrm{N} \text { 值 } 力 \\
\text { 孔内 }\end{array}$ & 平載不 & & $\begin{array}{l}=E_{50} \\
=700 \mathrm{~N} \\
=E_{b}\end{array}$ & $\begin{array}{l}\left.\mathrm{kN} / \mathrm{m}^{2}\right) \\
\left.\mathrm{NN} / \mathrm{m}^{2}\right) \\
\left.\mathrm{kN} / \mathrm{m}^{2}\right)\end{array}$ & $\begin{array}{c}\alpha=80 \\
\alpha=60 \\
\alpha=80\end{array}$ \\
\hline
\end{tabular}

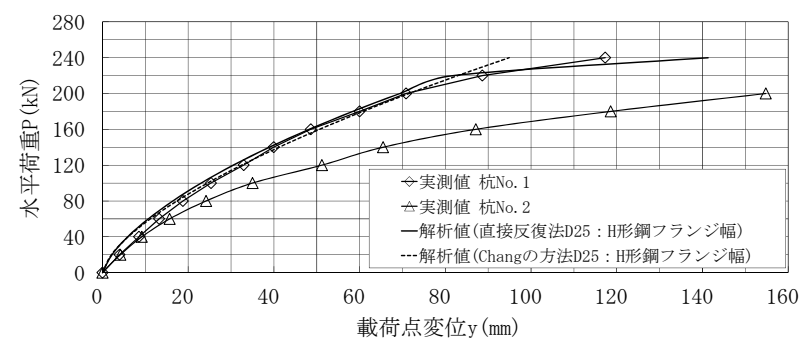

(a) 杭 No. 1, No. 2

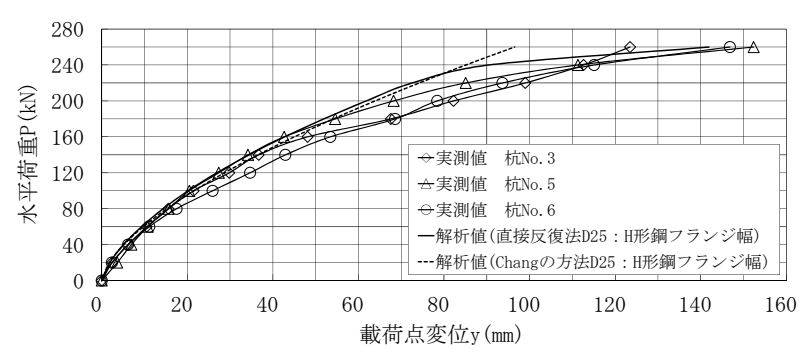

(b) 杭 No. 3 , No. 5 , №. 6

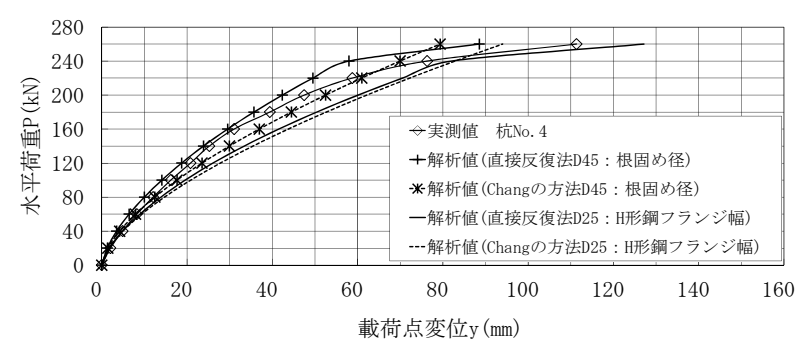

(c) 杭 No. 4

図 10 水平荷重 $\mathrm{P}$-載荷点変位 $\mathrm{y}$ 関係 


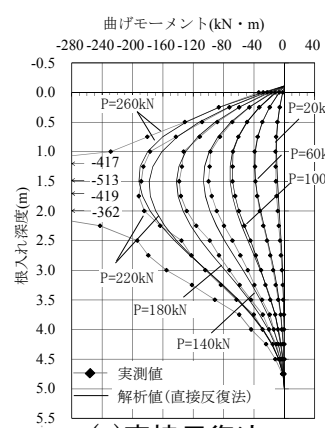

(a)直接反復法

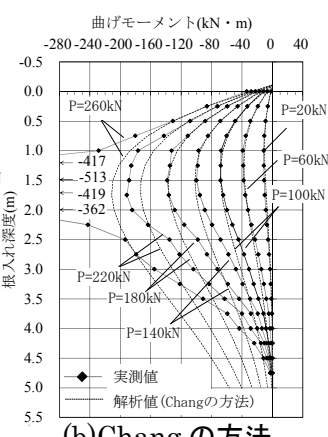

(b)Chang の方法
図 11 杭体応力の深度分布（杭 No. 4）

（2）Chang の方法に地盤の非線形性状を考慮することでも，載 荷点深度での杭体の荷重一水平関係をある程度精度良く解析できた。 山留め設計上重要な, 根切り底以浅の変位の予測方法としては, 実 用上問題が小さいと考えられる。

（3）直接反復法, Chang の方法ともに, 根固めの強度が原地盤 に対し十分大きければ, 解析上の杭の見付け幅として, 根固め径を 用いることができる。本実験では, 根固めの一軸圧縮強さが $219.8 \mathrm{kN} / \mathrm{m}^{2}$ と原地盤 $78.3 \sim 88.0 \mathrm{kN} / \mathrm{m}^{2}$ の約 2.5 倍であった杭 No.4 において, 根固めの効果を確認できた。なお, 本実験では材令が最 長 13 日と短く, 配合 Type1 では十分な根固めの効果が認められな かったが，表 3 に参考值として示した 28 日材令程度の強度が確保 できれば，根固め径を考慮可能と推察される。

\section{4. 山留め変位実測值の逆算に基づく関東ローム地盤の側圧係数}

\section{4-1 側圧係数の検討方法および事例の概要}

関東ローム地盤における山留め壁の変位実測值を用いた逆解析を 実施し，逆算した側圧係数（以下，逆算側圧係数）を種々の地盤定 数との関係で整理した。逆解析の対象は, 東京都内の 8 事例, 16 測点の自立山留めもしくは 1 次根切り時(根切り深さ $3.62 \sim 6.80 \mathrm{~m}$ ) の実測值である。表 5 に事例の主な特徴と土質試験結果および自立 高さを示す。一軸圧縮強さ $\mathrm{q}_{\mathrm{u}}$ は $82.0 \sim 163.5\left(\mathrm{kN} / \mathrm{m}^{2}\right)$, 細粒分含有 率は 84.1 92.7\%の範囲にある。表中の自立高さ hc, hc' は(4)式, (5)式で求めている。

$$
\begin{aligned}
& \mathrm{h}_{c}=2 c_{u} / \gamma \cdot \sqrt{\mathrm{K}_{\mathrm{p}}} \\
& \mathrm{h}_{c}{ }^{\prime}=\mathrm{q}_{u} / \gamma
\end{aligned}
$$

ここに, $\mathrm{K}_{\mathrm{p}}$ : 受働土圧係数 $\tan ^{2}\left(45^{\circ}+\phi_{\mathrm{u}} / 2\right), \mathrm{c}_{\mathrm{u}}$ : 三軸圧縮試験

(UU 条件) による粘着力度 $\left(\mathrm{kN} / \mathrm{m}^{2}\right), \phi_{\mathrm{u}}$ ：同試験による内部摩擦 角, $\gamma$ : 土の湿潤単位体積重量 (湿潤密度 $\times$ 重力加速度) $\left(\mathrm{kN} / \mathrm{m}^{3}\right)$, $\mathrm{q}_{\mathrm{u}}$ : 一軸圧縮強さ $\left(\mathrm{kN} / \mathrm{m}^{2}\right)$ 。

なお，いずれの事例においても地下水位は根切り底以深である。

\section{4-2 山留め解析方法および解析条件}

山留め解析は, 梁・ばねモデル12) による。本解析方法は, 山留 め壁，地盤を深さ方向に層分割し，各層の単位幅当りの基本方程式 を(6)式で与えている。同式の一般解に, 壁上下端の境界条件および 各層境界の連続条件を導入し, 山留め壁の応力, 変位および地盤反 力を算定している。

$$
\operatorname{EI} \frac{d^{4} y}{d x^{4}}+k_{h} B y=w
$$

ここに， E， I， y， x, $\mathrm{k}_{\mathrm{h}} ， \mathrm{~B}$ : (1)式と同定義， w : 単位幅あたり の荷重 $(\mathrm{kN} / \mathrm{m})$ を表す。

逆解析にあたっては，側圧と水平抵抗の両者が変数となるため, 仮定条件の設定方法の相違により，逆算側圧係数の算定結果も異な るが，本検討では，山留め設計における実用性を考慮して，以下の ように仮定した。

（1）根切り底以浅の側圧は三角形分布を仮定する

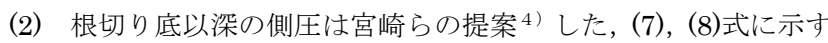
逆三角形分布とする。

砂質地盤 $: \mathrm{h}=3.0-0.1 \mathrm{~N}$

粘性土地盤 : $h=3.0-0.05 c$

ここに，h：根入れ部で外力として作用する側圧の深さ $(\mathrm{m})$ ，た だし， $\mathrm{h} \geqq 0.5, \mathrm{~N}: \mathrm{N}$ 值， $\mathrm{c}:$ 土の粘着力度 $\left(\mathrm{kN} / \mathrm{m}^{2}\right)$ を表す。

（3）地盤の水平抵抗は(2)，(3)式で評価する。 $\mathrm{E}_{0}$ の評価は，ローム および粘性土層においては一軸圧縮試験による $\mathrm{E}_{50}$, 砂質土層にお いては $\mathrm{E}_{0}=700 \mathrm{~N}\left(\mathrm{kN} / \mathrm{m}^{2}\right)$ を用いて $\mathrm{k}_{\mathrm{h} 0}$ を仮定し，根切り底深度にお ける変位 $\mathrm{y}$ の仮定值と解析值の誤差が $0.1 \mathrm{~mm}$ 未満, 山留め壁頭部

\begin{tabular}{|c|c|c|c|c|c|c|c|c|c|c|}
\hline \multicolumn{3}{|c|}{ 事例 } & $\mathrm{A}$ & B & $\mathrm{C}$ & $\mathrm{D}$ & E & F & G & $\mathrm{H}$ \\
\hline \multicolumn{3}{|c|}{ 主な土質 } & ローム & ローム & ローム & ローム & ローム & ローム & ローム & ローム \\
\hline \multicolumn{2}{|c|}{ 床付または1次根切り深さ } & $\mathrm{GL}-\mathrm{m}$ & 6.80 & 5.22 & 3.62 & 5.32 & 3.65 & 4.00 & 5.00 & 4.80 \\
\hline \multicolumn{2}{|c|}{ 根切り底以浅の平均N值 } & & 2.50 & 3.33 & 4.40 & 4.40 & 4.00 & 4.25 & 7.50 & 2.60 \\
\hline \multicolumn{2}{|c|}{ 土質試験試料採取深度 } & $\mathrm{GL}-\mathrm{m}$ & $5.0 \sim 5.8$ & $3.0 \sim 3.9$ & $2.0 \sim 2.85$ & $2.0 \sim 2.85$ & $5.0 \sim 6.0$ & $4.5 \sim 5.0$ & $3.0 \sim 4.0$ & $2.6 \sim 3.4$ \\
\hline \multicolumn{2}{|c|}{ 湿潤密度 } & $\mathrm{g} / \mathrm{cm}^{3}$ & 1.468 & 1.353 & 1.268 & 1.268 & 1.348 & 1.345 & 1.389 & 1.319 \\
\hline \multirow{2}{*}{\multicolumn{2}{|c|}{$\begin{array}{l}\text { 自然含水比 } \\
\text { 間隙比 } \mathrm{e}\end{array}$}} & $\%$ & 83.7 & 109.3 & 127.0 & 127.0 & 112.2 & 111.3 & 122.5 & 110.0 \\
\hline \multirow[t]{6}{*}{ 間隙比 } & & & 2.329 & 2.943 & 3.909 & 3.909 & 3.398 & 3.272 & 3.255 & 3.369 \\
\hline & 石分·砂分 & $\%$ & 0.0 & 0.0 & 0.0 & 0.0 & 0.0 & 0.0 & 0.0 & 0.0 \\
\hline & 砂分 & $\%$ & 15.0 & 7.8 & 7.3 & 7.3 & 10.0 & 11.3 & 15.9 & 8.2 \\
\hline & シルト分 & $\%$ & 41.1 & 34.3 & 32.9 & 32.9 & 53.2 & 56.2 & 65.2 & 46.9 \\
\hline & 粘土分 & $\%$ & 43.9 & 57.9 & 59.8 & 59.8 & 36.8 & 32.5 & 18.9 & 44.9 \\
\hline & 細粒分計 & $\%$ & 85.0 & 92.2 & 92.7 & 92.7 & 90.0 & 88.7 & 84.1 & 91.8 \\
\hline \multirow{2}{*}{ 一軸圧縮試験 } & $\mathrm{q}_{\mathrm{u}}$ & $\mathrm{kN} / \mathrm{m}^{2}$ & 82.0 & 136.0 & 163.5 & 163.5 & 83.8 & 157.0 & 125.6 & 115.3 \\
\hline & $E_{50}$ & $\mathrm{kN} / \mathrm{m}^{2}$ & 3,020 & 5,170 & 10,135 & 10,135 & 4,420 & 6,520 & 3,420 & 5,000 \\
\hline \multirow{2}{*}{ 二軸圧縮試験 (UU条件) } & $\mathrm{c}_{\mathrm{u}}$ & $\mathrm{kN} / \mathrm{m}^{2}$ & 44.0 & 62.2 & 76.8 & 76.8 & 57.4 & 65.7 & 58.3 & 107.5 \\
\hline & $\phi_{\mathrm{u}}$ & 度 & 6.5 & 5.1 & 10.0 & 10.0 & 10.8 & 10.1 & 4.3 & 14.3 \\
\hline \multicolumn{2}{|c|}{ 山留め壁仕様 } & $\begin{array}{l}\text { @: 打設 } \\
\text { 間隔, } \\
\text { L: 応力 } \\
\text { 材長さ }\end{array}$ & $\begin{array}{c}\mathrm{H} 400 * 400 * \\
13 * 21 \\
@ 1.5 \mathrm{~m} \\
\text { 測点 } 1 \\
\mathrm{~L}=13.5 \mathrm{~m} \\
\text { 測点 } 2 \\
\mathrm{~L}=11.5 \mathrm{~m} \\
\end{array}$ & $\begin{array}{c}\mathrm{H} 300 * 300 * \\
10 * 15 \\
@ 1.0 \mathrm{~m} \\
\mathrm{~L}=10.5 \mathrm{~m}\end{array}$ & $\begin{array}{c}\mathrm{H} 250 * 250 * \\
9 * 14 \\
@ 1.2 \mathrm{~m} \\
\mathrm{~L}=7.0 \mathrm{~m}\end{array}$ & $\begin{array}{c}\mathrm{H} 300 * 300 * \\
10 * 15 \\
@ 1.0 \mathrm{~m} \\
\mathrm{~L}=11.0 \mathrm{~m}\end{array}$ & $\begin{array}{c}\mathrm{H} 300 * 300 * \\
10 * 15 \\
@ 1.2 \mathrm{~m} \\
\mathrm{~L}=12.0 \mathrm{~m}\end{array}$ & $\begin{array}{c}\mathrm{H} 350 * 350 * \\
12 * 19 \\
@ 1.0 \mathrm{~m} \\
\mathrm{~L}=11.0 \mathrm{~m}\end{array}$ & $\begin{array}{c}\mathrm{H} 350 * 350 * \\
12 * 19 \\
@ 1.5 \mathrm{~m} \\
\mathrm{~L}=28.0 \mathrm{~m}\end{array}$ & $\begin{array}{c}\mathrm{H} 488 * 300 * \\
11 * 18 \\
@ 1.2 \mathrm{~m} \\
\mathrm{~L}=23.0 \mathrm{~m}\end{array}$ \\
\hline \multicolumn{2}{|c|}{ 根固め径 } & $\mathrm{m}$ & 0.60 & なし & なし & なし & 0.45 & なし & 0.50 & 0.65 \\
\hline \multirow{2}{*}{\multicolumn{2}{|c|}{$\begin{array}{l}\text { 二軸からの自立高さhc' } \\
\text { 三軸からの自立高さhc }\end{array}$}} & $\mathrm{m}$ & 5.70 & 10.26 & 13.16 & 13.16 & 6.34 & 11.91 & 9.23 & 8.92 \\
\hline & & $\mathrm{m}$ & 6.85 & 10.26 & 14.73 & 14.73 & 10.50 & 11.90 & 9.23 & 21.40 \\
\hline
\end{tabular}
変位 $\mathrm{y}$ の実測值と解析值との差が $0.1 \mathrm{~mm}$ 未満となるように収斂計

表 5 事例概要および土質試験結果 
算を行う。

（4）根切り底以深の側圧および水平抵抗の評価における杭の見付 け幅として，3 章を参考に，根固めがある事例では根固め径，ない 場合は H 形鋼のフランジ幅とする。これは, 通常の山留め施工時に 用いる配合と材令であれば，原地盤と比較して十分な根固め強度が 発現していることを想定したものである。

\section{4-3 側圧係数の逆算結果およびその考察}

図 12(a) (h)に, 逆算側圧係数での解析值を実測值と対比して示 した。事例 A， B，E，Fには，同一事例での複数測点があり，事例 C と D は同一敷地内における別工区の事例である。事例 $\mathrm{H}$ には, 同一測点での掘削直後の測定值と, 掘削深度に変化がなかった 1.5 ケ月後の測定值を併記している。逆解析において, 実測值との差が

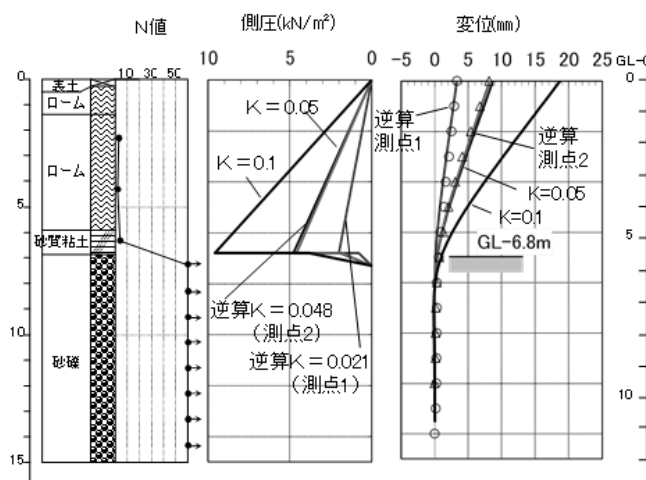

(a)事例 A

N值

変位 $(\mathrm{mm})$
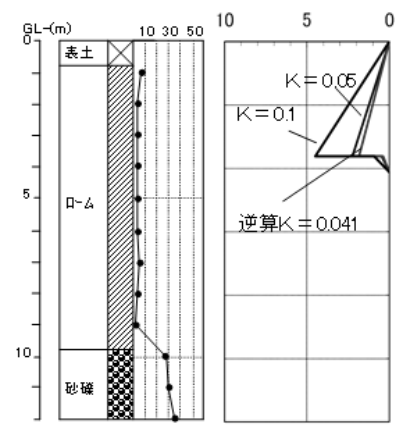

(c)事例 C

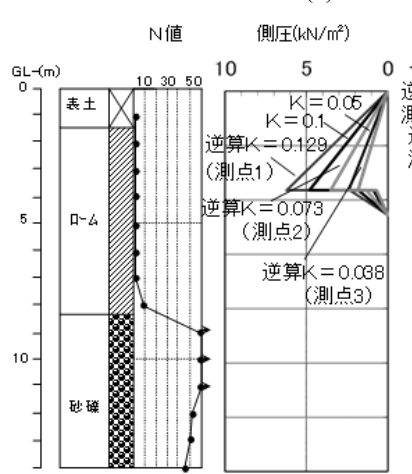

(e)事例 E

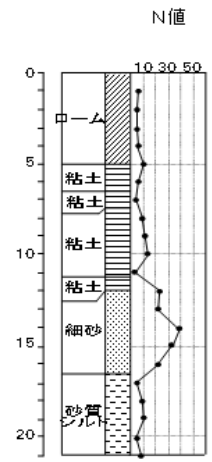

側圧 $\left(\mathrm{kN} / \mathrm{m}^{2}\right)$

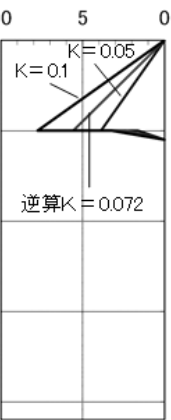

$(g)$ 事例 G
$0-50 \quad 5 \quad 101520253035$

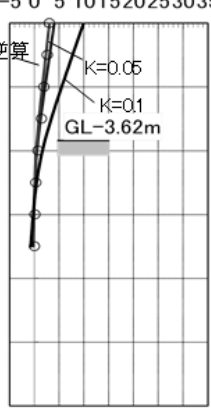

变位(min)

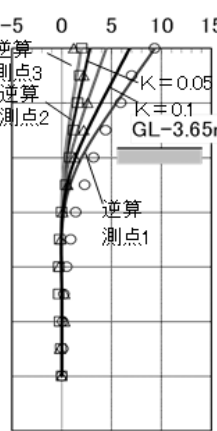

变位 $(m m)$

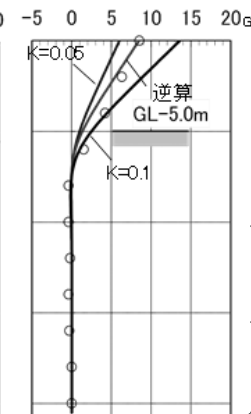

図 12 側圧および山留め壁変位
变位 $(\mathrm{mm})$

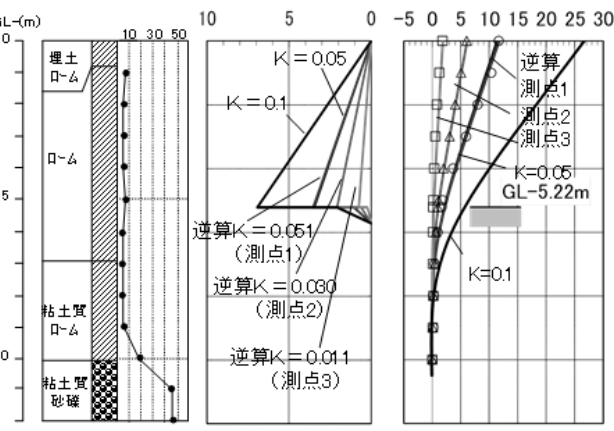

(b)事例 B

变位( $(\mathrm{m} n)$

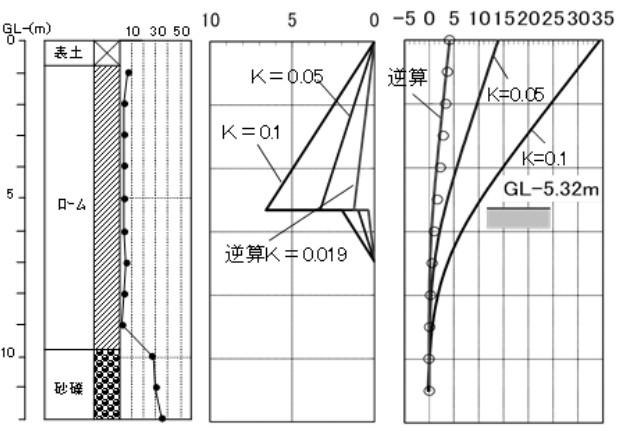

(d)事例 D

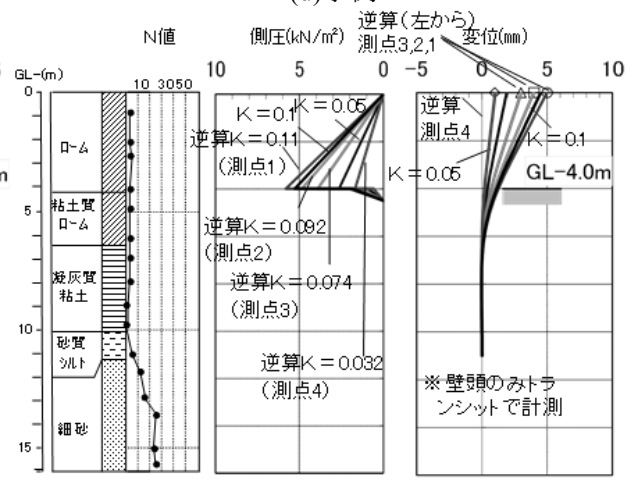

(f) 事例 F

N値 側圧 $\left(\mathrm{kN} / \mathrm{m}^{2}\right)$

\section{変位( $(\mathrm{mm})$}

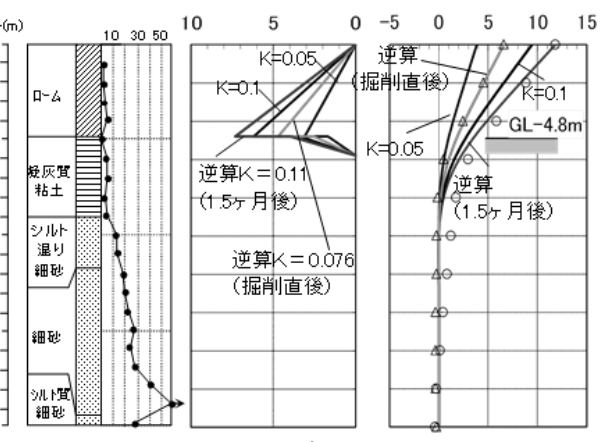

(h)事例 H 


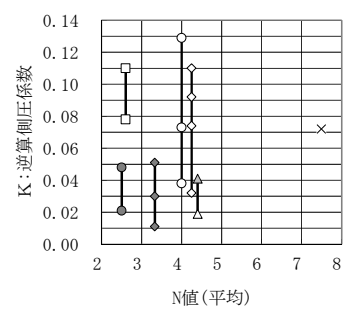

(a) 根切り底以浅の平均N值

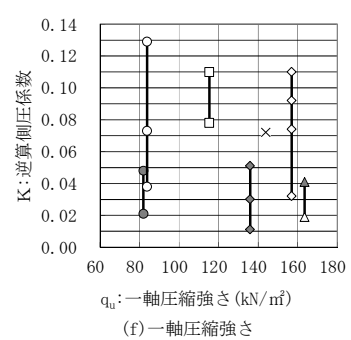

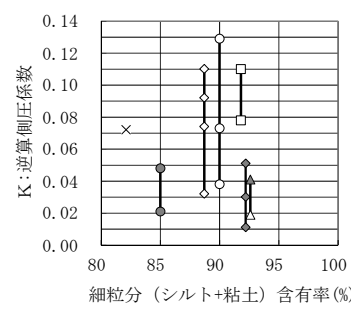

(b) 細粒分含有率

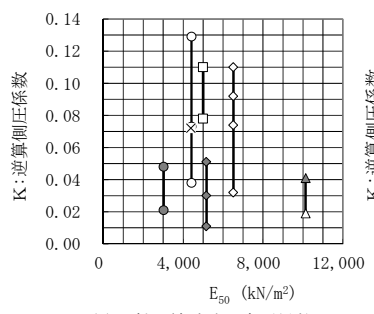

(g) 一軸圧縮試験の変形係数 $\mathrm{E}_{50}$

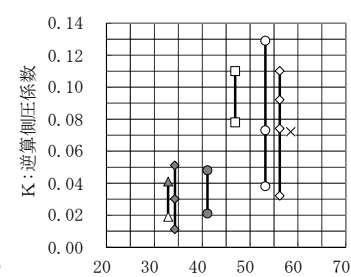

シルト分含有率 $(\%)$

(c) シルト分含有率

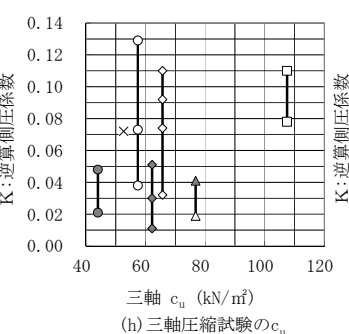

(h) 三軸圧縮試験の

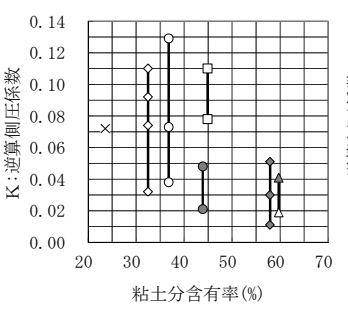

(d) 粘土分含有率

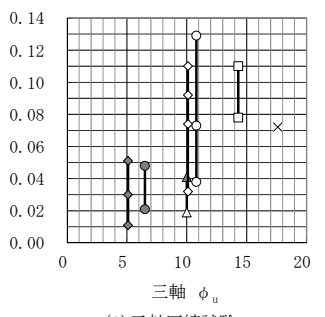

(i) 三軸圧縮試験の $\phi_{u}$

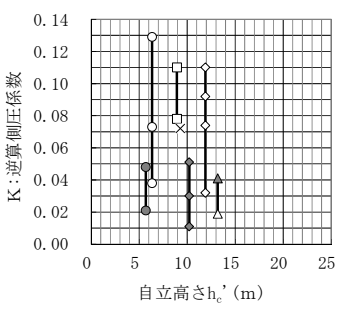

(e) 自立高さ $h_{c}{ }_{c}^{\prime}$

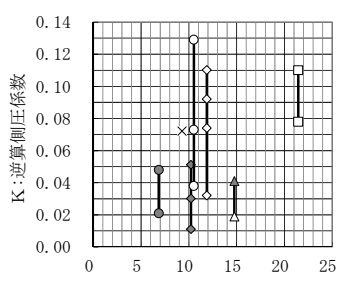

自立高さhc (m)

(j) 自立高さ $h_{c}$

\begin{tabular}{|c|c|c|c|c|c|c|c|}
\hline O事例A & $\diamond$ 事例B & $\Delta$ 事例C & $\Delta$ 事例D & O事例E & $\diamond$ 事例F & X事例G & 口事例H \\
\hline
\end{tabular}

図 13 逆算側圧係数と地盤定数との関係

$0.1 \mathrm{~mm}$ 未満の壁頭変位を与える側圧係数を逆算側圧係数とした。た だし，事例 $\mathrm{E} の$ 測点 $2 ， 3$ は，実測の壁頭変位が地中部変位より小 さいため, GL-2.0m における変位量を用いて同様の判定をしている。 図中には側圧係数を $0.05 ， 0.10$ とした場合の解析結果を併記した。 また図 13(a)〜(j)に，逆算側圧係数と土質試験結果等との関係を示 した。順に，(a)標準貫入試験の $\mathrm{N}$ 值，(b)細粒分含有率，(c)シルト 分含有率, (d) 粘土分含有率, $(\mathrm{e})$ 自立高さ $\mathrm{h}_{\mathrm{c}}{ }^{\prime},(\mathrm{f}) \cdot(\mathrm{g})$ 一軸圧縮強さ $q_{u}$ および変形係数 $E_{50},(h) \cdot(\mathrm{i})$ 三軸圧縮試験 $(\mathrm{UU}$ 条件)の粘着力度 $\mathrm{c}_{\mathrm{u}}$ およびせん断抵抗角 $\phi \mathrm{u},(\mathrm{j})$ 自立高さ $\mathrm{h}_{\mathrm{c}}$ との関係で整理している。 上記による，関東ローム地盤の側圧の傾向を以下にまとめる。

（1）逆算側圧係数は，0.011〜0.129 の範囲に分布したが， $\mathrm{N}$ 值， 力学試験結果, 粒度分布, 自立高さとの明瞭な関係は認められなか った。また, 同一事例でほぼ同一の地盤・施工条件であっても, 絶 対值は小さいものの逆算側圧係数にはばらつきが認められる。

(2) 各事例の逆算側圧係数の最小值のみに着目寸ると, 8 事例中 6 件が 0.05 未満, 8 事例全てが 0.1 未満であった。また, 定性的では あるが，逆算側圧係数は，三軸圧縮試験の $\phi_{\mathrm{u}}$ が大きいほど大きく， 粘土分含有率が高いほど小さくなる傾向が認められる。

（3）事例 $\mathrm{H}$ では，掘削深度に変化がないにも関わらず，1.5 ケ月 経過後に変位が増大している。

同一事例で同一掘削深さであっても，逆算側圧係数に差異が生じ た主な要因として，1)平面位置による地層構成のばらつき，2)山留
め壁の施工精度の差異, 3)背面地盤に作用寸る重機荷重などの仮設 荷重の影響, 4)降雨などによる掘削後の経時的な状沉変化, などが 挙げられる。このことから, 精度よく山留め壁を施工し, 慎重に掘 削工事を行うことで，山留め壁の変位量を抑制することが可能であ るといえるが，計画時の現実的な対応としては，ある程度の地盤条 件や施工のばらつき, 計画外の重機荷重や工程の遅延などを想定し たうえで側圧や地盤抵抗を評価する必要があろう。

\section{5. 関東ローム地盤における山留め設計時の側圧と水平抵抗の評価}

前章までの検討結果から，関東ローム地盤の山留め設計における 側圧と地盤反力の評価法を提示するとともに，側圧係数を 0.05 と 0.1 とした場合の山留め解析における水平変位量の余裕度を示す。

\section{5-1 山留め解析における側圧係数および水平抵抗の評価}

山留め壁の水平変位算定における解析条件は以下とする。

（1）解析方法は，(6)式に示す梁・ばねモデルによる。

（2）側圧は側圧係数法による三角形分布とし, 根切り底以深は(7), (8)式による逆三角形分布とする。

（3）基準水平地盤反力係数 $\mathrm{k}_{\mathrm{h} 0}$ は(3)式で評価し, 浅い根切り山留 め工事においても一般的に調査されることが多い，一軸圧縮試験結 果（粘性土）または標準貫入試験結果（砂質土）を用いる。水平地 盤反力係数 $\mathrm{k}_{\mathrm{h}}$ は以下の 2 通りを検討した。

表 6 山留め計算結果および余裕度（側圧係数 $\mathrm{K}=0.05 ）$

\begin{tabular}{|c|c|c|c|c|c|c|c|c|c|c|c|c|c|c|c|c|c|c|c|c|c|}
\hline & & & & & $\mathrm{A}$ & $\mathrm{A}$ & B & $\mathrm{B}$ & $\mathrm{B}$ & $\mathrm{C}$ & $\mathrm{D}$ & $\mathrm{E}$ & $\mathrm{E}$ & $\mathrm{E}$ & $F$ & $\mathrm{~F}$ & $F$ & $F$ & $G$ & $\mathrm{H}$ & $\mathrm{H}$ \\
\hline 側圧係数 & 項目 & 位置 & 記号 & & 測点1 & 測点2 & 測点1 & 測点2 & 測点3 & 測点1 & 測点1 & 測点1 & 測点2 & 測点3 & 測点1 & 測点2 & 測点3 & 測点4 & 測点1 & $\begin{array}{l}\text { 掘削 } \\
\text { 直後 }\end{array}$ & \begin{tabular}{|c|}
1.5 个月 \\
後
\end{tabular} \\
\hline \multirow{12}{*}{$\mathrm{K}=0.05$} & \multirow{2}{*}{ 実測変位 } & 壁頭部 & $\mathrm{y}_{\mathrm{tm}}$ & mm & 3.30 & \begin{tabular}{|l|}
8.13 \\
\end{tabular} & 11.66 & 6.03 & 1.79 & 3.00 & 4.09 & 9.30 & 1.20 & 2.00 & 5.00 & 4.00 & 3.00 & 1.00 & 8.50 & 6.56 & 11.79 \\
\hline & & 根切り底 & $\mathrm{y}_{\mathrm{gm}}$ & $\mathrm{mm}$ & 0.67 & 0.84 & 1.60 & 0.99 & 0.15 & 0.97 & 1.42 & 3.66 & 1.64 & 0.95 & 2.00 & 1.60 & 1.20 & 0.40 & 2.85 & 1.65 & 4.67 \\
\hline & \multirow{2}{*}{ 弹塑性解析値 } & 壁頭部 & $\mathrm{y}_{\mathrm{t}, \mathrm{cl}}$ & $\mathrm{mm}$ & 11.70 & 11.70 & 15.86 & 15.86 & 15.86 & 9.99 & 18.26 & 4.90 & 4.90 & 4.90 & 3.66 & 3.66 & 3.66 & 3.66 & 8.95 & 6.41 & 6.41 \\
\hline & & 根切り底 & $\mathrm{y}_{\mathrm{gcc} \mathrm{c}}$ & $\mathrm{mm}$ & 1.12 & 1.12 & 3.85 & 3.85 & 3.85 & 2.55 & 4.93 & 1.57 & 1.57 & 1.57 & 1.22 & 1.22 & 1.22 & 1.22 & 2.04 & 2.22 & 2.22 \\
\hline & \multirow{2}{*}{$\begin{array}{c}\text { 余裕度 } \\
\text { 弾塑性/実測 }\end{array}$} & 壁頭部 & $\mathrm{y}_{\mathrm{t} . \mathrm{l}} / \mathrm{y}_{\mathrm{t}, \mathrm{m}}$ & & 3.55 & 1.44 & 1.36 & 2.63 & 8.86 & 3.33 & 4.46 & 0.53 & 4.08 & 2.45 & 0.73 & 0.91 & 1.22 & 3.66 & 1.05 & 0.98 & 0.54 \\
\hline & & 根切り底 & $\mathrm{y}_{\mathrm{gccl}} / \mathrm{y}_{\mathrm{gm}}$ & & 1.67 & 1.33 & 2.40 & 3.89 & 26.23 & 2.63 & 3.47 & 0.43 & 0.96 & 1.65 & 0.61 & 0.76 & 1.02 & 3.05 & 0.72 & 1.35 & 0.48 \\
\hline & \multirow{2}{*}{ 非線形解析値 } & 壁頭部 & $\mathrm{y}_{\mathrm{t} c \mathrm{c} 2}$ & $\mathrm{~mm}$ & 8.69 & \begin{tabular}{|l|}
8.69 \\
\end{tabular} & 11.34 & 11.34 & 11.34 & 4.00 & 13.87 & 2.83 & 2.83 & 2.83 & 1.90 & 1.90 & 1.90 & 1.90 & 6.01 & 3.85 & 3.85 \\
\hline & & 根切り底 & $\mathrm{y}_{\mathrm{g}, \mathrm{c} 2}$ & $\mathrm{~mm}$ & 0.49 & \begin{tabular}{|l|}
0.49 \\
\end{tabular} & 2.10 & 2.10 & 2.10 & 0.77 & 3.11 & 0.64 & 0.64 & 0.64 & 0.44 & 0.44 & 0.44 & 0.44 & 0.99 & 1.02 & 1.02 \\
\hline & \multirow{2}{*}{$\begin{array}{c}\text { 余裕度 } \\
\text { 非線形 / 実測 }\end{array}$} & 壁頭部 & $\mathrm{y}_{\mathrm{t} . \mathrm{c} 2} / \mathrm{y}_{\mathrm{t} . \mathrm{m}}$ & & 2.63 & 1.07 & 0.97 & 1.88 & 6.34 & 1.33 & 3.39 & 0.30 & 2.36 & 1.42 & 0.38 & 0.47 & 0.63 & 1.90 & 0.71 & 0.59 & 0.33 \\
\hline & & 根切り底 & $\mathrm{y}_{\mathrm{gcc} \cdot 2} / \mathrm{y}_{\mathrm{g} \mathrm{m}}$ & & 0.73 & 0.58 & 1.31 & 2.12 & 14.31 & 0.79 & 2.19 & 0.17 & 0.39 & 0.67 & 0.22 & 0.27 & 0.36 & 1.09 & 0.35 & 0.62 & 0.22 \\
\hline & \multirow{2}{*}{$\begin{array}{l}\text { 比率(参考値) } \\
\text { 弾塑性/非線形 }\end{array}$} & 壁頭部 & $\mathrm{y}_{\mathrm{t}, \mathrm{cl} / \mathrm{y}_{\mathrm{t}, \mathrm{C}}}$ & & 1.35 & 1.35 & 1.40 & 1.40 & 1.40 & 2.50 & 1.32 & 1.73 & 1.73 & 1.73 & 1.93 & 1.93 & 1.93 & 1.93 & 1.49 & 1.66 & 1.66 \\
\hline & & 根切り底 & $y_{\mathrm{gcc}} / \mathrm{y}_{\mathrm{g} c \mathrm{c}}$ & & 2.29 & \begin{tabular}{|l|}
2.29 \\
\end{tabular} & 1.83 & 1.83 & 1.83 & 3.31 & 1.59 & 2.45 & 2.45 & 2.45 & 2.80 & 2.80 & 2.80 & 2.80 & 2.06 & 2.18 & 2.18 \\
\hline
\end{tabular}


表 7 山留め計算結果および余裕度（側圧係数 K=0.1）

\begin{tabular}{|c|c|c|c|c|c|c|c|c|c|c|c|c|c|c|c|c|c|c|c|c|c|}
\hline & & & & & A & A & B & B & B & C & D & E & E & E & $\mathrm{F}$ & $\mathrm{F}$ & $\mathrm{F}$ & $\mathrm{F}$ & G & $\mathrm{H}$ & $\mathrm{H}$ \\
\hline 側圧係数 & 項目 & 位置 & 記号 & & 測点1 & 測点2 & 測点1 & 測点2 & 測点3 & 測点 1 & 測点1 & 測点1 & 測点 2 & 測点3 & 測点1 & 測点 2 & 測点3 & 測点 4 & 測点 1 & $\begin{array}{l}\text { 掘削 } \\
\text { 直後 }\end{array}$ & $\begin{array}{c}1.5 \text { 月 } \\
\text { 後 }\end{array}$ \\
\hline \multirow{12}{*}{$\mathrm{K}=0.1$} & \multirow{2}{*}{ 実測変位 } & 壁頭部 & $\mathrm{y}_{\mathrm{t}, \mathrm{m}}$ & $\mathrm{mm}$ & 3.30 & \begin{tabular}{|l|}
8.13 \\
\end{tabular} & 11.66 & 6.03 & 1.79 & 3.00 & 4.09 & 9.30 & 1.20 & 2.00 & 5.00 & 4.00 & 3.00 & 1.00 & 8.50 & 6.56 & 11.79 \\
\hline & & 根切り底 & $\mathrm{y}_{\mathrm{gm}}$ & $\mathrm{mm}$ & 0.67 & 0.84 & 1.60 & \begin{tabular}{|l|}
0.99 \\
\end{tabular} & 0.15 & 0.97 & 1.42 & 3.66 & 1.64 & 0.95 & 2.00 & 1.60 & 1.20 & 0.40 & 2.85 & 1.65 & 4.67 \\
\hline & \multirow{2}{*}{ 弹塑性解析値 } & 壁頭部 & $\mathrm{y}_{\mathrm{tccl}}$ & $\mathrm{mm}$ & \begin{tabular}{|l|}
23.40 \\
\end{tabular} & 23.40 & 31.73 & 31.73 & 31.73 & 20.02 & 36.53 & 9.79 & \begin{tabular}{|l}
9.79 \\
\end{tabular} & \begin{tabular}{|l}
9.79 \\
\end{tabular} & 7.32 & 7.32 & 7.32 & 7.32 & 17.88 & 12.81 & 12.81 \\
\hline & & 根切り底 & $\mathrm{y}_{\mathrm{gccl}}$ & $\mathrm{mm}$ & 2.23 & 2.23 & 7.71 & 7.71 & 7.71 & 5.11 & 9.87 & 3.14 & 3.14 & 3.14 & 2.44 & 2.44 & 2.44 & 2.44 & 4.07 & 4.43 & 4.43 \\
\hline & \multirow{2}{*}{$\begin{array}{c}\text { 余裕度 } \\
\text { 弹塑性/実測 } \\
\end{array}$} & 壁頭部 & $\mathrm{y}_{\mathrm{t} . \mathrm{cl}} / \mathrm{y}_{\mathrm{t} \mathrm{m}}$ & & \begin{tabular}{|l|}
7.09 \\
\end{tabular} & 2.88 & \begin{tabular}{|l|}
2.72 \\
\end{tabular} & 5.26 & 17.73 & 6.67 & 8.93 & 1.05 & 8.16 & 4.90 & 1.46 & 1.83 & 2.44 & 7.32 & 2.10 & 1.95 & \begin{tabular}{|l|}
1.09 \\
\end{tabular} \\
\hline & & 根切り底 & $\mathrm{y}_{\mathrm{gcc}} / \mathrm{y}_{\mathrm{gm}}$ & & 3.33 & 2.65 & 4.81 & 7.80 & 52.52 & 5.27 & 6.95 & 0.86 & 1.91 & 3.31 & 1.22 & 1.53 & 2.03 & 6.10 & 1.43 & 2.68 & 0.95 \\
\hline & \multirow{2}{*}{ 非線形解析値 } & 壁頭部 & $\mathrm{y}_{\mathrm{t.c2} 2}$ & $\mathrm{~mm}$ & 18.70 & 18.70 & 26.66 & 26.66 & 26.66 & 9.91 & 34.42 & 6.81 & 6.81 & 6.81 & 4.51 & 4.51 & 4.51 & 4.51 & 13.61 & 9.45 & 9.45 \\
\hline & & 根切り底 & $\mathrm{y}_{\mathrm{g} c 2}$ & $\mathrm{~mm}$ & 1.22 & 1.22 & 5.66 & 5.66 & 5.66 & 2.23 & 9.05 & 1.76 & 1.76 & 1.76 & 1.15 & 1.15 & 1.15 & 1.15 & 2.49 & 2.82 & 2.82 \\
\hline & \multirow{2}{*}{$\begin{array}{c}\text { 余裕度 } \\
\text { 非線形/央測 } \\
\end{array}$} & 壁頭部 & $\mathrm{y}_{\mathrm{t} . \mathrm{c}} / \mathrm{y}_{\mathrm{tm}}$ & & 5.67 & 2.30 & 2.29 & 4.42 & 14.89 & 3.30 & 8.42 & 0.73 & 5.68 & 3.41 & 0.90 & 1.13 & 1.50 & 4.51 & 1.60 & 1.44 & 0.80 \\
\hline & & 根切り底 & $\mathrm{y}_{\mathrm{gc} c 2} / \mathrm{y}_{\mathrm{gm}}$ & & 1.82 & 1.45 & 3.53 & 5.72 & 38.56 & 2.30 & 6.37 & 0.48 & 1.07 & 1.85 & 0.58 & 0.72 & 0.96 & 2.88 & 0.87 & 1.71 & 0.60 \\
\hline & \multirow{2}{*}{$\begin{array}{l}\text { 比率(参考値) } \\
\text { 弹塑性/非線形 }\end{array}$} & 壁頭部 & $\mathrm{y}_{\mathrm{t} . \mathrm{cl} /} / \mathrm{y}_{\mathrm{t} .2}$ & & 1.25 & 1.25 & \begin{tabular}{|l|l|}
1.19 \\
\end{tabular} & 1.19 & 1.19 & 2.02 & 1.06 & 1.44 & 1.44 & 1.44 & 1.62 & 1.62 & 1.62 & 1.62 & 1.31 & 1.36 & 1.36 \\
\hline & & 根切り底 & $1 / \mathrm{y}_{\mathrm{g}, \mathrm{c} 2}$ & & 1.83 & 1.83 & 1.36 & $\begin{array}{l}1.36 \\
\end{array}$ & 1.36 & 2.29 & 1.09 & 1.78 & 1.78 & 1.78 & 2.12 & 2.12 & 2.12 & 2.12 & 1.63 & 1.57 & 1.57 \\
\hline
\end{tabular}

方法 $1:$ 杭体の水平変位が $1 \mathrm{~cm}$ までは線形弾性とし, $\mathrm{k}_{\mathrm{h}}=\mathrm{k}_{\mathrm{h} 0}$ の一 定值とする。水平変位 $1 \mathrm{~cm}$ に到達した時の地盤反力を上限值とする 方法 (以下, 弾塑性解析)。

方法 2 : 山留め計算で得た根切り底深度の杭体の水平変位量 $\mathrm{y}_{\mathrm{g}}$ を(2) 式に適用して水平地盤反力係数 $\mathrm{k}_{\mathrm{h}}$ を再評価し， $\mathrm{y}_{\mathrm{g}}$ の誤差が $0.1 \mathrm{~mm}$ 未満となるように収斂計算する方法（以下，非線形解析）。

（4）根切り底以深の側圧および水平抵抗の評価における杭の見 付け幅として, 4-2 節と同様に, 根固めがある事例では根固め径, ない場合は H 形鋼のフランジ幅とする。

（5）山留め壁変位量の余裕度は, 解析による変位量を実測変位量 で除した值として定義する。

\section{5-2 山留め変位量の解析結果および余裕度}

表 6，表 7 は，側圧係数をそれぞれ $0.05 ， 0.1$ とした弾塑性解析 および非線形解析結果のうち, 壁頭部および根切り底深度の変位量 を抽出したものである。また，これらの実測変位量に対する比を変 位の余裕度として示した。変位の余裕度は, 弾塑性解析によると, 側圧係数を 0.05 とした場合, 壁頭部において $0.53 \sim 4.08$ （極めて 余裕度の大きな事例 $\mathrm{B}$ の測点 3 を除く, 以下同様), 根切り底深度 において $0.43 \sim 3.89$ に分布し, 側圧係数を 0.1 とした場合, 壁頭部 において 1.05〜8.93, 根切り底深度において 0.86〜 7.80 に分布し た。また, 非線形解析による变位の余裕度は, 側圧係数を 0.05 とし た場合，壁頭部において $0.30 \sim 3.39$, 根切り底深度において 0.17 〜 2.19 に分布し, 側圧係数を 0.1 とした場合, 壁頭部において 0.73 〜 8.42, 根切り底深度において $0.48 \sim 6.37$ に分布した。

山留め壁変位量の余裕度として 1.0 を目安とすると，本検討に用 いた事例と同等の地盤条件であれば，弾塑性解析に側圧係数 0.1 を 導入することで，概ね安全側の結果が得られるといえよう。また， $4-3$ 節で示したように，事例ごとの逆算側圧係数の最小值が概ね 0.05 未満であることを勘案すると, 側圧係数 $0.05 \sim 0.1$ の範囲での 弾塑性解析や非線形解析による山留め設計も可能と考えられるが, 掘削中の計測管理に加え, 山留め壁の施工精度や掘削手順, 仮設荷 重などに十分配慮する必要がある。

\section{6. まとめ}

関東ローム地盤のような自立性の高い地盤における山留め設計時 の側圧および水平抵抗の評価法を検討した結果を以下にまとめる。

（1）親杭横矢板山留めでは, 根固めの強度を原地盤に対し十分大
きくすることで，根固めが親杭(H 形鋼) と一体挙動し，水平抵抗の 増加に寄与することが実大実験および解析結果から明らかとなった。 （2）杭体および地盤の非線形性状を考慮した直接反復法により, 親杭根入れ部の水平挙動を精度良く解析可能である。水平地盤反力 係数の評価には, 一軸圧縮試験の変形係数 $\mathrm{E}_{50}$ から基準水平地盤反 力係数 $\mathrm{k}_{\mathrm{h} 0}$ を求め, これを杭体水平変位量の平方根に反比例させる 方法を導入した。

（3）関東ローム地盤における 8 事例，16 測点（一軸圧縮強さ $\mathrm{q}_{\mathrm{u}}=82.0 \sim 163.5\left(\mathrm{kN} / \mathrm{m}^{2}\right)$, 細粒分含有率 $\left.=84.1 \sim 92.7 \%\right)$ の山留め 変位実測結果から逆算した側圧係数は, $0.011 \sim 0.129$ の範囲に分布 した。同一事例でほぼ同一の地盤・施工条件であっても，絶対值は 小さいものの逆算側圧係数にはばらつきが認められた。

（4）梁・ばねモデルを用いた関東ローム地盤での親杭横矢板山留 め設計時の判断の目安として, 側圧係数を $0.05,0.1$ とした場合の 山留め変位量の余裕度を事例解析により示した。地盤ばねを弾塑性 とし，水平地盤反力係数を一軸圧縮試験結果（粘性土）または標準 貫入試験結果 (砂質土) から評価した方法に側圧係数 0.1 を導入し, 根切り底以深の側圧を(7), (8)式に示す逆三角形分布とすることで, 山留め壁変位量の余裕度が概ね 1.0 を上回った。

\section{参考文献}

1）風間了: 実測変形から見た軟弱地盤における山留め外力分布, その 11 次根切り時, 日本建築学会構造系論文集, 第 514 号, pp.141-148, 1998.12

2）風間了: 実測変形から見た軟弱地盤における山留め外力分布, その 2 根 切りの進行に伴う外力分布, 日本建築学会構造系論文集, 第 532 号, pp.95-102, 2000.6

3）日本建築学会：山留め設計施工指針, pp.77-81, 2002.2

4）宮崎祐助：実測に基づく山留め設計用外力に関する研究，日本建築学会 構造系論文集，第 458 号, pp.59-68, 1994.4

5）石井健太郎，他 3 名：関東ローム地盤における親杭横矢板山留めの矢板 計測, 日本建築学会大会学術講演梗概集 B-1, pp.723-724, 2004.8

6) 石崎長俊, 丸隆宏 : 洪積地盤における横矢板が負担する側圧, 日本建築 学会大会学術講演梗概集 B-1, pp.751-752, 2004.8

7）日本建築学会：山留め設計施工指針，pp.132-136，2002.2

8）元井康雄，他 4 名：関東ロームにおける親杭の水平抵抗（その $1 \sim 3$ ), 第 45 回地盤工学研究発表会平成 22 年度発表講演集, pp.1252-1257, 2010.8

9）土質工学会 : 杭の水平載荷試験方法・同解説，1983.10

10）日本建築学会 : 建築基礎構造設計指針, pp.268-282, 2001.10

11）日本建築センター：建築物のための改良地盤の設計及び品質管理指針, p355, 2002.11

12）日本建築学会 : 山留め設計施工指針, pp.123-124, 2002.2 


\section{LATERAL EARTH PRESSURE AND LATERAL SUBGRADE REACTION OF BRACELESS EARTH RETAINING WALLS IN KANTO LOAM GROUND}

\section{Yasuo MOTOI*}

\footnotetext{
* Chief Research Engineer, Geotechnical Engineering Department, Technical Research Institute, Obayashi Corp., M. Eng.
}

Lateral pressure and lateral subgrade reaction for designing earth retaining in Kanto loam ground were examined using field measurement, full scale horizontal load test, and analysis.

1. At earth retaining using soldier piles and lagging method, by enlarging intensity of cement bentonite enough to ground, cement bentonite carries out an action united with a soldier pile, and contributes to the increase in horizontal resistance. This character was clarified by the result of full scale horizontal load test, and the analysis result.

2. The lateral performance of soldier piles is analyzable with sufficient accuracy using the direct repeat method in consideration of nonlinearity of soldier piles and ground. The direct repeat method is one of the analysis methods that transposes piles to beams and transposes ground to Winkler springs. Coefficient of lateral subgrade reaction is made in inverse proportion to the square root of lateral displacement of a pile. Coefficient of lateral subgrade reaction is based on a value in case lateral displacement of a pile is $1 \mathrm{~cm}$. This value is calculated from the deformation modulus $\mathrm{E}_{50}$ of an unconfined compression test result.

3. Coefficient of lateral earth pressure counted backward from the actual measurement of displacement of earth retaining walls of 8 sites (16 points) in Kanto loam ground was distributed from 0.011 to 0.129 . The unconfined compressive strength of all the data is distributed from 82.0 to $163.5\left(\mathrm{kN} / \mathrm{m}^{2}\right)$, and fine-grain fraction content is $84.1 \%$ to $92.7 \%$. There was a difference in Coefficient of lateral earth pressure counted backward of another point in the same site in spite of the almost same ground and construction conditions. However, the absolute value of the difference is small.

4. The analysis method using the Winkler type spring model for designing earth retaining using soldier piles and lagging method in Kanto loam ground was shown. The spring of ground was transposed to elasto-plasticity and coefficient of lateral subgrade reaction was evaluated from the unconfined compression test result or the standard penetration test result. By evaluating as 0.1 coefficient of lateral earth pressure used for this method, safety margin of displacement of earth retaining walls exceeded 1.0 in general. Moreover, if the ground conditions are equivalent to the examples of this paper, in the design of earth retaining, coefficient of lateral earth pressure may be able to be set as the range of 0.05 to 0.1. However, sufficient consideration is required so that prudent construction and control by measuring may be performed. 